\title{
(Pre)živjeti unutar dubrovačke stare jezgre - priča 0 Gradu iz perspektive lokalnog stanovništva
}

\author{
Nika $\boldsymbol{\oplus}$ uho \\ Hrvatsko katoličko sveučilište, Odjel za sociologiju, Zagreb, Hrvatska \\ e-mail:nika.djuho@unicath.hr
}

Maja Golubić

Hrvatsko katoličko sveučilište, Odjel za sociologiju, Zagreb, Hrvatska e-mail:mgolubic@unicath.hr

\section{Karlo Tukša}

Hrvatsko katoličko sveučilište, Odjel za sociologiju, Zagreb, Hrvatska e-mail:ktuksa@unicath.hr

SAŽETAK Cilj rada bio je istražiti simboličko značenje i iskustvo života unutar dubrovačke stare jezgre. Dubrovačka stara jezgra ima značenjsku razliku spram drugih dijelova gradova, a danas je prepoznata i kao svjetska turistička destinacija. Proučavana problematika istražena je na primjeru lokalnog stanovništva - u istraživanju je sudjelovalo devet sudionika koji su rođeni i dandanas žive unutar jezgre. U sklopu ovog istraživanja korištena je kvalitativna metodologija, u dvije faze. U prvoj fazi istraživanja korištena je metoda narativnog urbanizma - prikupljanje podataka kroz razgovor i šetnju lokalitetima unutar jezgre, kroz koje su nas vodili sami sudionici. U drugoj fazi istraživanja primijenjena je tehnika polustrukturiranog intervjua na istom uzorku lokalnog stanovništva. Glavni nalazi ukazuju na to kako su dostupnost različitih sadržaja te ambijentalna posebnost glavni aspekti privlačnosti za život unutar stare jezgre. Uz aspekte privlačnosti, stječe se dojam kako lokalno stanovništvo postaje žrtva vlastite povijesti i kulture, kroz istaknute primjere uzurpacije svakodnevice i percepcije života u nestajanju. Međutim, detaljnija analiza pokazat će da identitet lokalnog stanovništva nije statičan te da se ostvaruje kroz dvije naizgled proturječne, a ipak komplementarne kategorije - kategoriju stanovnika i kategoriju domaćina turistima.

Ključne riječi: dubrovačka stara jezgra, lokalno stanovništvo, narativni urbanizam, priča o gradu. 


\section{Uvod}

Dubrovačka stara jezgra ima značenjsku razliku i osobitost spram drugih dijelova grada. Njena značajnost proizlazi iz vremenitosti, civilizacijskih i kulturnih tvorbi koje su upisali povijesni događaji. Kulturna i povijesna osobitost čine je privlačnim mjestom za život, a u uvjetima sveprisutne globalizacije (turizma) i prepoznatom svjetskom turističkom destinacijom. S obzirom na to da je dubrovačka stara jezgra istovremeno mjesto života i turističko odredište, ona se neprestano mijenja - u fizičkom (prostornom) i socijalnom smislu. S protokom vremena i utjecajem turizma mjesta se mijenjaju, nadodaju im se ili oduzimaju pojedine karakteristike, a time i stavovi, vrijednosti i značenja za one koji taj prostor svakodnevno koriste. Slikovito rečeno, dubrovačka stara jezgra ostaje ista u (fizičkim) okvirima, ali nikad u (simboličkim) pojedinostima. Sveukupna kulturna baština (materijalna i nematerijalna) danas se koristi kao ključan turistički element privlačnosti, a dubrovačka stara jezgra ne predstavlja iznimku. Kada govorimo o turizmu, autorica Jelinčić (2006.: 165) navodi kako osim ekonomski, turizam najčešće pridonosi ulaganju i očuvanju kulturne baštine, prirodnih ljepota i atraktivnosti nekog mjesta. U simboličkom i identitetskom smislu turizam može potaknuti samosvijest, ponos ili samopouzdanje kod lokalnog stanovništva. Međutim, velike gužve, buka, visoke cijene, manjak funkcionalnog sadržaja, okupiranost javnog prostora, estetska banalizacija kulturne baštine ili problemi u prometu koji nastaju kao posljedice turizma prema autoru Rogiću (1992.: 42) mogu narušiti ukupnu kvalitetu života lokalnog stanovništva.

Danas postoji veći broj znanstvenih radova koji problematiziraju grad, kulturu i tradiciju kao turistički proizvod ili se pak usmjeravaju isključivo na posljedice turizma na grad, njegovu kulturu i simboličku značajnost. Međutim, tek se manji broj znanstvenih radova orijentira na svakodnevna iskustva običnih ljudi koji većinu svog vremena i svakodnevnih aktivnosti baziraju unutar prostora stare jezgre. Pritom se zanemaruje čitav raspon i intenzitet ljudskih iskustava koja se talože u nekom značenjskom prostoru. Iz spomenutog razloga $u$ istraživanju je korištena pješačka perspektiva ${ }^{1} u$ nastojanju da se istaknu iskustva života unutar stare jezgre iz perspektive lokalnog stanovništva. Podaci su prikupljeni metodom narativnog urbanizma i polustrukturiranog intervjua. Koncept narativnog urbanizma oslanja se na razinu svakodnevnog i mikropolitičkog - riječ je o proizvodnji (sa)znanja o gradu, urbanitetu, ali i o ljudima koji u njemu žive (Leboš, 2009.: 85, prema Krasny 2007.). Takva metoda omogućava proizvodnju čitljivosti grada, ali i onih koji u njemu obitavaju.

\footnotetext{
${ }^{1}$ Michael de Certeau (1998.: 93) koristi pojam pješačke perspektive grada kao perspektivu „odozdo“, iz koje se grad poima kroz svakodnevno korištenje. Ona uključuje življenje u gradu te upisivanje značenja u prostor. Upravo kroz življenje ili korištenje prostora, hodanjem, šetanjem ili provođenjem vremena lokaliteti stječu odliku familijarnosti ili bliskosti.
} 
Cilj ovog istraživanja bio je istražiti iskustvo života unutar dubrovačke stare jezgre nastojanjem dobivanja odgovora na sljedeća pitanja: (1) postoje li mjesta od simboličkog značaja za lokalnu zajednicu, (2) koje su percipirane prednosti i nedostaci života unutar stare jezgre te (3) kakav je odnos lokalnog stanovništva prema staroj jezgri kao turističkom središtu, ali i mjestu života. U radu je korištena kvalitativna metodologija, kojoj je cilj steći dublji uvid u proučavanu problematiku. Prema autorima Čaldarović i Šarinić (2017.: 60), dosadašnja istraživanja s istom tematikom primijenjena na različite lokalitete ukazuju na zaključak kako je za procjenu ukupnog i specifičnog kapaciteta javnog prostora i kvalitete života u sociološkom smislu najadekvatnije koristiti i oslanjati se upravo na spomenute metode istraživanja.

\section{Koncept mjesta}

Biti čovjek znači živjeti u svijetu koji je ispunjen značajnim mjestima: biti čovjek znači imati svoje mjesto. (Relph, 1976.: 1)

Za razumijevanje koncepta mjesta može nam poslužiti Castellsova (2000.: 438) podjela na prostor tokova i prostor mjesta. Prostori tokova globalnog su karaktera, obilježeni tokovima kretanja kapitala i autonomnim mehanizmima, koji samo načelno imaju prostornu dimenziju. Oni nemaju povijesno značenje, zbog čega ih se nerijetko povezuje s pojmom nemjesta (engl. placelessness) (Relph, 1976.: 143). Prostori tokova kao nemjesta imaju jasno utvrđenu, instrumentalnu funkciju. Prema Baumanu (2011.: 103), glavna je funkcija nemjesta da se „kroz njih prođe i ostavi za sobom što je brže moguće“. Prema Relphu (1976.: 144), nemjesta su neautentična mjesta, beživotni okviri bez povijesti, osobnosti i karaktera. Suprotno od pojma prostora tokova i nemjesta, pojam mjesta upotrebljavamo kada mislimo na konkretna fizička mjesta. Autor Tuan (1977.: 2) pod pojam mjesta svrstava nekoliko kategorija: (1) cjelokupnu površinu Zemlje, (2) jedinice mjesta poput regija, grada, sela ili naselja, (3) specifičnu jedinicu nekog mjesta (stanovi, poslovne zgrade, parkovi, ulice, trgovi) ili (4) lokaciju, odnosno poziciju nekoga ili nečega. Iako se danas prostorom i mjestom bave sociolozi, antropolozi i drugi stručnjaci, jednu od obuhvatnijih definicija mjesta ponudio je geograf Fred Lukermann. Na temelju promišljanja koncepta mjesta Lukermann (1964.: 167-172) ističe šest ključnih karakteristika mjesta: (1) mjesta su konkretni fizički prostori, koji se razlikuju po veličini, površini i lokalitetu koji zauzimaju u fizičkoj gradskoj strukturi, (2) mjesta uključuju interakciju prirodnih i kulturnih elemenata, zbog čega je svako mjesto jedinstven entitet, (3) iako su mjesta jedinstvena ona mogu biti slična ovisno o značenju, simbolici, povijesti i identitetu, (4) mjesta su određena praksama života stanovnika, (5) mjesta se kontinuirano stvaraju i obnavljaju, s povijesnim i kulturnim promjenama novi se elementi pridodaju mjestima, dok drugi nestaju, (6) mjesta omogućuju društveni život i stvaranje socijalnih interakcija među susjedima. Ukoliko bismo se usmjeravali samo na koncept prostora tokova, onda bismo izostavili cijeli niz svakodnevnih interakcija i praksi kroz koje se prostor svakodnevno stvara i 
(pre)oblikuje (u značenjsko mjesto). Mjesta kao konkretne fizičke prostore svakodnevnim procesima proizvodnje, posvajanja i teritorijalizacije oblikuje lokalno stanovništvo. Iako po općim karakteristikama mjesta mogu biti međusobno slična, njihova različitost proizlazi iz lokalne ekspresivnosti, koja je određena svakodnevnim praksama stanovnika, što proizvodi njihovu različitost u fizičkom i simboličkom smislu (Relph, 1976.: 11). Mjesta su oblikovana praksama života stanovnika, procesom oplemenjivanja fizičkog prostora navikama, kulturom i običajima koji se odvijaju unutar njih, što se još naziva procesom „umještanja lokalnog“ (Gulin Zrnić, 2009.: 29). S tog aspekta korisno bi bilo razlikovati dva ključna pojma autorice Low (2006.: 92): društvenu proizvodnju i društveno oblikovanje prostora. Kada govorimo o društvenoj proizvodnji prostora, onda mislimo na plansku izgradnju različitih dijelova grada, koja ovisi o urbanističkim, arhitektonskim, društvenim, ekonomskim, političkim i tehnološkim čimbenicima. Proces proizvodnje prostora obuhvaća brojne aktivnosti koje su unaprijed jasno definirane: odlučivanje, planiranje, projektiranje, izgradnja ili održavanje prostora. Kada govorimo o društvenom oblikovanju prostora, onda mislimo na transformaciju fizički izgrađenog prostora u značenjsko mjesto. U proces oblikovanja prostora uključeni su i sami stanovnici, što proizlazi iz svakodnevnog života unutar fizičkog prostora, zbog čega možemo govoriti o specifičnom fenomenološkom, simboličkom, ali i autobiografskom iskustvu prostora (Gulin Zrnić, 2009.: 19). Prema Tuanu (1977.: 73), transformacija prostora u mjesto nastaje onda kada prostor stekne odliku familijarnosti ili bliskosti, pri čemu se ponajprije misli na taloženje iskustava i simboličkih značenja koja se pripisuju mjestima. Osim što mjesta imaju simboličko značenje, ona su povijesna, uporišna i identitetska mjesta. Sve navedeno, naravno, nije moguće bez interakcije, komunikacije i razmjene iskustava među stanovnicima, kroz što se stvara i određeni osjećaj povezanosti ili socijalne kohezije. S tog aspekta mjesta mogu biti privatna, osobna i javna (Lipovec, 1997.: 6-7). Privatna su mjesta fizička mjesta, mogu biti i privatna i javna, a povezana su s psihološkim značenjima i od simboličke su važnosti za svakog pojedinca. „Privatno“ ne znači da takva mjesta nužno pripadaju samo jednom pojedincu. Privatno mjesto može biti mjesto neke grupe ili zajednice (kao mjesto susreta). Pojedinci ili grupe najčešće javni prostor (poput ulica, trgova, zgrada, parkova, rekreacijskih zona) transformiraju u privatna mjesta. To ne znači da svi članovi zajednice dijele isto značenje. Mjesta su okviri koji nam dopuštaju razmjenu simbola i simboličkih značenja. S tog aspekta govorimo o kolektivnoj značajnosti mjesta. No, jednako tako ona su uvijek sadržana u našim osobnim iskustvima i sjećanjima u odnosu na taj prostor, stoga djelomično i osobna (Lipovec, 1997.: 6-7). Osim političkih, kulturnih, ekonomskih ili drugih utjecaja, treba stoga naglasiti ulogu lokalnog stanovništva u održavanju i oblikovanju mjesta. Nije riječ samo o fizičkim atributima, već i o socijalnim faktorima koji doprinose duhu mjesta. Mjesta nastaju i preoblikuju se kroz prisutnost drugih, njihovih aktivnosti i očekivanja u prostoru (Relph, 1976.: 23). 


\section{Kvaliteta života}

Konceptom kvalitete života danas se koriste mnoge znanstvene discipline te se svaka od njih usmjerava prema aspektima koji odgovaraju specifičnostima struke. U kontekstu sociologije koncept kvalitete života nije jasno određen, no postoje različiti pokušaji konceptualizacije tog pojma kako bi se istaknula problemska područja, otkrila razina i uzroci (ne)zadovoljstva te kako bi se uputilo na prioritete i smjer razvoja učinkovitih politika (Čaldarović i Šarinić, 2017.: 59). U najširem smislu, kvaliteta života odnosi se na ugodno stanovanje u nekom mjestu, koje omogućuje zadovoljavanje fizičkih, ali i širih društvenih, ekonomskih, kulturnih i obrazovnih potreba (Seferagić, 1988.: 17). U nastavku iznosimo nekoliko različitih konceptualizacija koncepta kvalitete života, koji pretežito nastoje definirati kvalitetu života u kvantitativnim kategorijama.

Prvi pristup, onaj autorice Slavuj (2012.: 71), naglašava kako u kontekstu istraživanja kvalitete života treba obratiti pozornost na nekoliko čimbenika: promet (dostupnost parkinga, kvaliteta prometnica, održavanje i kontrola prometa), dostupnost (različite javne usluge), socijalne veze (interakcija ljudi i socijalna kohezija članova) te sigurnost susjedstva (opušteno svakodnevno funkcioniranje i stvaranje socijalnih interakcija).

Prema drugom pristupu, onom autorice Seferagić (1988.: 17), koncept kvalitete života svodi se na nekoliko ključnih aspekata, koji su dijelom obuhvaćeni prvim pristupom: stanovanje (opremljenost, stambeni fond, izdaci za stan), promet (parking, javni prijevoz), prirodni okoliš (kvaliteta vode, zraka, buka, količina zelenih površina, urednost javnog prostora), dostupnost usluga i sadržaja (javne usluge u širem smislu riječi), socijalne veze u susjedstvu (odnosi sa susjedima, spremnost na pomoć) te sigurnost susjedstva.

Treći pristup obuhvaća aspekte koji su obuhvaćeni prvim i drugim pristupom te ih konceptualizira na tri razine: objektivni indikatori, subjektivni indikatori te bihevioralni indikatori (Vukić, 2019.: 14, prema Marans i Stimens, 2011.: 3). Pod objektivne indikatore ubrajamo infrastrukturnu opremljenost naselja, dostupnost usluga i sadržaja, prometnu povezanost, kvalitetu zraka, gustoću stanovanja, stopu nezaposlenosti, obrazovnu strukturu stanovništva, cijenu nekretnina, stopu kriminala i slično. Pod subjektivne indikatore ubrajamo zadovoljstvo stanovnika stanovanjem i susjedstvom, percepciju sigurnosti okoline, zadovoljstvo sadržajima i uslugama, zadovoljstvo zdravljem, okolinom, obiteljskim i poslovnim mogućnostima, koje je moguće istraživati na razini kvartova ili pojedinih gradova. Pod bihevioralne indikatore ubrajamo ponašanje stanovnika i njihovo sudjelovanje u različitim aktivnostima - korištenje javnog prijevoza, bavljenje sportom i rekreacijom, navike druženja, participacija u udrugama ili lokalnoj samoupravi te donošenje odluka na lokalnoj razini.

No, osim općeg pojma kvalitete života, potrebno je istaknuti sociološku konceptualizaciju kvalitete javnih prostora, koji imaju značajnu ulogu u percepciji opće kvalitete 
života. Kada govorimo o vrijednosti javnog prostora, potrebno je razlikovati njegovu upotrebnu i komercijalnu vrijednost (Čaldarović i Šarinić, 2017.: 9). Komercijalna vrijednost javnog prostora danas je često prenaglašena, a proizlazi isključivo iz odnosa ponude i potražnje. Ugodnost, upotrebljivost, prikladnost i ispunjenost javnog prostora sadržajima koji zadovoljavaju potrebe lokalnog stanovništva karakteristike su javnog prostora koji ima upotrebnu vrijednost. Valjalo bi voditi računa da postoji ravnoteža između spomenutih vrijednosti. No, često se događa da jedna poništava drugu, i to najčešće u korist komercijalne vrijednosti prostora. U Hrvatskoj, prema autorima Čaldarović i Šarinić (2017.: 142), posebno su ugroženi centri gradova kao povijesno važni prostori, gdje se uočava kršenje zakona o zaštiti baštine pod vodstvom kapitala, iseljavanje siromašnijeg stanovništva, prilagodba prostora isključivo komercijalnim ili turističkim sadržajima, što se danas skupno naziva procesom turistifikacije (prilagođavanje aktivnosti turističkoj potražnji). Jedan od najboljih primjera spomenutih procesa upravo je dubrovačka stara jezgra, koja je u fokusu ovog istraživanja.

Osim spomenutih vrijednosti javnog prostora, prema autorima Čaldarović i Šarinić (2017.: 60), u sociološkoj procjeni javnog prostora u obzir treba uzeti nekoliko ključnih dimenzija: dostupnost, otvorenost, pristupačnost, opremljenost, način korištenja, prostorni smještaj, veličinu, urbani parter i omogućene režime korištenja. Kada je riječ o funkciji javnog prostora, sociološka analiza uzima u obzir sljedeće elemente: privlačnost, način korištenja, organizaciju prostora, fizičke i simboličke transformacije, (ne) atraktivnosti, stavove o postojećim javnim prostorima i slično (Čaldarović i Šarinić, 2017.: 62). Na kraju, čini se važnim istaknuti univerzalne kvalitete javnog prostora (Vukić, 2019.: 34, prema Carmoni i dr, 2008.: 15): čistoću i urednost, pristupačnost, atraktivnost, ugodnost, inkluzivnost, vitalnost i živost, funkcionalnost, distinktivnost, sigurnost, izdržljivost, zelenilo i nezagađenost te ispunjenost (osjećaj pripadanja).

\section{Dosadašnja istraživanja}

Jedno od najranijih istraživanja starih gradskih jezgri u Hrvatskoj prikazano je u Rogićevoj (1992.) knjizi Periferijski puls u srcu od grada. Rogić (1992.: 29) ističe kako stare jezgre imaju privlačnu snagu za život čak i onda kada su prema objektivnim mjerilima kvalitete života inferiorne u odnosu na druge dijelove grada. Njihova inferiornost proizlazi iz nekoliko trendova s kojima se stare jezgre suočavaju: demografsko propadanje (smanjenje broja lokalnog stanovništva i porast broja starog stanovništva koje je izašlo iz radnog kontingenta), ekologijska zapuštenost (zapuštenost javnih prostora, komunalna neopremljenost), funkcionalna neselektivnost sadržaja i usluga (prevlast komercijalnih nad upotrebnim sadržajima) te simbolička banalizacija (kulturne baštine, autentičnosti prostora i društvenih običaja). Od ukupnog broja ispitanika koji žive unutar dubrovačke stare jezgre njih 53,7\% istaknulo je iznimnu prljavštinu i neurednost javnih prostora kao glavni nedostatak života unutar stare jezgre. Osim toga, ispitanici su naveli (45\%) nedostatak ustanova za osobe starije životne dobi i djecu. Nezadovoljstvo je iskazano i u pogledu sljedećih aspekata: komunalna opremljenost 
(36\%), nerazvijeno zdravstvo (33\%), neurednost javnih prostora i skupo održavanje kuća i stanova $(28,3 \%)$, veliki i brojni izvori buke $(22,3 \%)$ te je $20,7 \%$ njih istaknulo slabe trgovačke usluge (Rogić, 1992.: 29-34).

Autori Vidak i Sindik (2013.: 130) uočili su snažan utjecaj turizma na svakodnevni život lokalnog stanovništva kroz porast cijena nekretnina, iseljavanje iz stare gradske jezgre, buku, gužve, visoke cijene, nedostatak društvenih i kulturnih sadržaja, zimski osjećaj praznine i komercijalizaciju javnog prostora. Također, autori su uočili i trendove transformacije sadržaja u isključivo turističke svrhe (proces turistifikacije), što izaziva funkcionalnu neselektivnost na štetu javnog interesa navodeći kako se u nastojanju za ostvarivanjem što većeg profita otvaraju suvenirnice, dok se zatvaraju prodavaonice živežnih namirnica te mali tradicionalni obrti (Vidak i Sindik, 2013.: 113).

Autori Klempić Bogadi, Vukić i Čaldarović (2018.) proveli su sustavnu sociološko-demografsku studiju o životu unutar dubrovačke stare jezgre. Na pitanje o zadovoljstvu kvalitetom života unutar stare jezgre čak $40 \%$ ispitanih odgovorilo je da uopće nije zadovoljno ili da je poprilično nezadovoljno kvalitetom života. Nadalje, čak 37,9\% ispitanika navelo je kako unutar stare jezgre ljudi žive puno ili donekle lošije (Klempić Bogadi, Vukić i Čaldarović, 2018.: 68). Kao glavne prednosti života unutar stare jezgre ispitanici su istaknuli blizinu sadržaja $(32,2 \%)$, ljepotu ambijenta $(32,5 \%)$ i život u pješačkoj zoni (19,2\%). Među osnovnim nedostacima ispitanici su navodili nedostatak parkinga $(69,2 \%)$, gužvu $(42 \%)$, nedostatak trgovina $(40,8 \%)$ te buku $(32,1 \%)$, a među njima se istaknulo i nezadovoljstvo komunalnom infrastrukturom i urednošću javnog prostora (Klempić Bogadi, Vukić, Čaldarović, 2018.: 102-103). Drugim riječima, i nakon dvadesetak godina stanje unutar dubrovačke stare jezgre nije se znatnije poboljšalo. Autori Klempić Bogadi, Vukić i Čaldarović (2018.: 103) zaključuju da je za zadržavanje postojećeg stanovništva i podizanja kvalitete života nužno provesti nekoliko mjera: (1) reguliranje i planiranje turističkog opterećenja jezgre, (2) uspostavljanje i održavanje sigurnosti i komunalnog reda te (3) osiguranje bolje opskrbe svakodnevnim potrepštinama unutar stare jezgre.

Iako su dosadašnja istraživanja dominantno kvantitativna, njihovi su nalazi poslužili kao inspiracija za konceptualizaciju ovog kvalitativnog istraživanja te usmjerila dubinsko istraživanje specifičnih odrednica kvalitete života iz perspektive lokalnog stanovništva.

\section{Metodologija i pristup istraživanju - iskustva lokalnog stanovništva}

Ovo je istraživanje primarno fenomenološko. Fenomenološka istraživanja uz dubinski pristup nastoje razumjeti istraživani fenomen oslanjajući se na doživljeno iskustvo sudionika istraživanja, njihov način osmišljavanja i pridavanja značenja tim iskustvima (Creswell, 2007.: 30). Cilj ovog rada bio je istražiti iskustvo i kvalitetu života unutar dubrovačke stare jezgre iz perspektive lokalnog stanovništva, koje svakodnevno stječe, 
stvara i oblikuje svoje iskustvo i sukladno ga tome može anticipirati. Zbog potrebe za što dubljim uvidom u proučavanu problematiku u istraživanju je korišten isključivo kvalitativni istraživački pristup. Kvalitativni istraživački pristup smatra se opravdanim izborom još od čikaške škole urbane sociologije pa sve do danas, u kontekstu urbane sociologije, urbane antropologije i urbane geografije (Low, 2006.: 13). Konkretno, u ovom radu korištena je metoda narativnog urbanizma te metoda polustrukturiranih intervjua. Narativni urbanizam metoda je kojoj je cilj opisati život neke društvene skupine hodom kroz grad, obilaskom svakodnevnih ruta kroz konverzaciju, što omogućuje refleksiju i produkciju prostora (Kalčić, 2013.: 80). Narativni urbanizam pristupa urbanizmu kao kulturi ili načinu života gradskih stanovnika koju oni aktivno proizvode, svjesno ili nesvjesno, u nekom prostoru (Krasny, 2015.) ${ }^{2}$. Takva metoda omogućava proizvodnju „čitljivosti“ grada, ali i onih koji u njemu obitavaju. Sudionici šetnjom (praksa jedan na jedan) kroz svakodnevne rute dijele svoju osobnu „umještenu“ priču koju dijele s istraživačem Sudionici su istraživače proveli kroz svakodnevne rute unutar dubrovačke stare jezgre, koje su birali spontano i samostalno. Kroz šetnju sudionici su opisivali i pričali svoja iskustva, bitne momente, situacije koje su vezane za specifičnu rutu ili lokalitet. Svi podaci snimani su putem mobitela te spremljeni u audiozapisu. Uz narativni urbanizam, podatke smo u drugoj fazi istraživanja prikupljali tehnikom polustrukturiranog intervjua na istom uzorku lokalnog stanovništva. Prednost primjene navedene tehnike vidimo u tome što je prilikom konverzacije moguće postaviti niz pitanja koja istraživač nije predvidio, a pokazuju se važnima kroz konverzaciju sa sudionicima. Prije provedbe istraživanja sudionici su bili upoznati s ciljem i svrhom istraživanja te su izrađeni obrasci suglasnosti kao potvrda pristanka sudjelovanja u istraživanju.

U istraživanju je sudjelovalo ukupno devet sudionika. Istraživanje je provedeno tijekom studenog 2017. godine. Uzorak primijenjen u ovom istraživanju je namjeran, a kriterij uzorkovanja bio je da su sugovornici rođeni te dandanas žive unutar stare jezgre. Kod uzorkovanja ponajprije smo se koristili tehnikom snježne grude. Svaki sudionik intervjuiran je pojedinačno (praksa jedan na jedan), a prikupljanje podataka (u prvoj fazi narativni urbanizam, u drugoj polustrukturirani intervju) u prosjeku je trajalo od 45 do 60 minuta. Uzorak je sastavljen od sudionika koji se međusobno razlikuju prema spolu (četiri sudionika i pet sudionica), dobi (mlađa, srednja i starija životna dob, u rasponu od 25 do 70 godina) i obrazovanju (tri sudionika/ica imaju završeno srednjoškolsko obrazovanje, pet sudionika/ica završenu višu stručnu spremu te jedan sudionik/ica završen magisterij). ${ }^{3} \mathrm{Na}$ spomenutu diferencijaciju sudionika možemo gledati kao izranjajući efekt dubinskog istraživanja, jer iz naočigled različitih pozicija tragamo za ponavljajućim obrascima i sličnostima iskustava (Creswell, 2007.: 37).

\section{2 http://www.zarez.hr/clanci/pravo-na-grad-i-pravo-na-zeleno}

3 T. P. - 26 god., VSS, community manager; A. R. - 33 god., SSS, konobarica; D. M. - 36 god., VŠS, nautičar; T. K. - 24 god., VŠS, studentica; P. D. - 70 god., VŠS, umirovljenica; A. S. - 24 god., VSS, studentica; S. H. - 71 god., SSS, umirovljenik; I. R. - 30 god., SSS, student; R. P. - 53 god., VŠS, inkorespondent. 
Intervjui su bili ostvareni kroz nekoliko specifičnih tema: (1) slika grada (doživljaj grada i specifična mjesta), (2) percipirane prednosti i nedostaci života unutar jezgre te (3) poželjni modeli razvoja iz perspektive lokalnog stanovništva. Vodič za pitanja konstruirali su istraživači. Nakon prikupljenih podataka uslijedila je transkripcija, popraćena minutažom i pseudonimima sudionika kako bi se zadržala anonimnost. Nakon procesa transkripcije uslijedilo je kodiranje podataka s ciljem dohvaćanja esencije istraženog fenomena za konačni izvještaj koji slijedi.

\section{Slika stare jezgre}

Osim što se pojedina susjedstva ili četvrti mogu promatrati kao konkretna mjesta u koja su upisana lokalna značenja, i unutar njih postoje određeni lokaliteti ili uporišna mjesta koja se ističu svojom simbolikom i važnošću za identitet njihovih stanovnika. Hodom kroz grad sudionici su nas spontano vodili do mjesta i lokaliteta od osobnog i kolektivnog značaja. Većinom, sva su istaknuta mjesta izmamila pozitivne uspomene, zbog čega možemo zaključiti da imaju upotrebnu vrijednost (doprinose ugodnosti, prikladnosti i vitalnosti). Lokalitet je jedna od temeljnih odrednica mjesta, ali ne i dovoljna, ono sa sobom nosi značenja i iskustva koja su u njemu upisana (Relph, 1976.: 29). Sudionici su istaknuli tri uporišna mjesta: kupalište Porporela, Crkva sv. Vlaha i glavna ulica - Stradun. U tablici 1 prikazani su iskazi sudionika o spomenutim lokalitetima.

Tablica 1.

Istaknuti lokaliteti i citati sudionika prikupljeni „hodom kroz grad“

\begin{tabular}{|l|l|l|}
\hline \multicolumn{2}{|c|}{ NAZIV LOKALITETA } \\
\hline \multicolumn{1}{|c|}{ Kupalište Porporela } & \multicolumn{1}{|c|}{ Crkva sv. Vlaha } & \multicolumn{1}{c|}{ Glavna ulica - Stradun } \\
\hline Tradicija se poštuje i održava (I. R.) & $\begin{array}{l}\text { Nije samo zaštitnik grada nego nas } \\
\text { je spasio u ratu, vjerujemo u njega, } \\
\text { stujemo i poštujemo ga (S. H.) }\end{array}$ & $\begin{array}{l}\text { Naš dardin, igralište i djetinjstvo (D. } \\
\text { M.) }\end{array}$ \\
\hline $\begin{array}{l}\text { Jedno od rijetkih mjesta koje se nije } \\
\text { promijenilo i u kojemu je zadržan } \\
\text { duh (T. K.) }\end{array}$ & $\begin{array}{l}\text { Tu su mi se roditelji oženili, tu smo } \\
\text { kršteni, svaka festa, blagdan i mise su } \\
\text { neizostavne (T. K.) }\end{array}$ & $\begin{array}{l}\text { Neki to smatraju turističkom } \\
\text { atrakcijom, dok nama to ima skroz } \\
\text { drukčije značenje (P. D.) }\end{array}$ \\
\hline $\begin{array}{l}\text { Ovdje ne vrijede pravila kakva vrijede } \\
\text { u ostatku Grada (D. M.) }\end{array}$ & $\begin{array}{l}\text { Crkva je simbol grada za mene, tu } \\
\text { sam provodio jako puno vremena, } \\
\text { cekajući prijatelje (T. P.) }\end{array}$ & Drugi dom (A. S.) \\
\hline $\begin{array}{l}\text { Mjesto djetinjstva, mladosti i prve } \\
\text { ljubavi (A. R.) }\end{array}$ & $\begin{array}{l}\text { Stalno sam tu, to je naše hajmo reći } \\
\text { (D. M.) }\end{array}$ & $\begin{array}{l}\text { Ne treba mu nijedan logo, on je to što } \\
\text { jest sam po sebi (I. R.) }\end{array}$ \\
\hline $\begin{array}{l}\text { Svako jutro idem na Porporelu baciti } \\
\text { pogled prema Lokrumu (S. H.) }\end{array}$ & $\begin{array}{l}\text { Najdraži dio grada, tu smo se igrali } \\
\text { kao djeca, imala sam sré́u odrasti u } \\
\text { gradu, i danas imam tradiciju naći } \\
\text { se s prijateljima ovdje, sjest i gledati } \\
\text { prolaznike (A. S.) }\end{array}$ & Najljepša šetnjica na svijetu (A. R.) \\
\hline
\end{tabular}


U svom istraživanju autor Stiperski (2015.: 341) došao je do zaključka da su lokalnom stanovništvu najprivlačnija ona mjesta koja imaju povijesno-kulturnu tradiciju, u odnosu na administrativna i uslužna mjesta. Poznato lokalno okupljalište - kupalište Porporela istaknulo se kao mjesto na kojemu nisu vidljive vizualne i druge funkcionalne promjene koje su vidljive u drugim dijelovima stare jezgre. Njezinu izvornost sudionici su povezivali s postojanjem „lokalnog duha“ i zajedništva, što upućuje na odnos identitetske privrženosti lokalnog stanovništva prema tom mjestu. Crkva sv. Vlaha istaknuta je u dvostrukom smislu: povijesno-kulturnom te socijalno-simboličkom. U povijesno-kulturnom smislu crkva kao simbol grada izgrađena je još u 18. stoljeću, a osim specifičnog fizičkog lokaliteta ona je istovremeno utvrda i odraz tradicije, koja se jednakom mjerom štuje i danas. U socijalno-simboličkom smislu prostor crkve ima važnost u odvijanju formalnih i neformalnih događaja u svakodnevnom životu lokalnog stanovništva. Tako su sudionici istaknuli formalne događaje poput krštenja, krizmi i vjenčanja, ali je ističu i kao mjesto svakodnevnih susreta, razgovora i dokolice. Stradun kao glavna ulica također je istaknuta u dvostrukom smislu: estetskom (ambijentalnom) te socijalno-simboličkom. U estetskom smislu posebnost glavne ulice proizlazi iz njene ambijentalne posebnosti, rijetkosti i autentičnosti. $S$ druge strane, $u$ socijalno-simboličkom smislu njezina vrijednost proizlazi iz svakodnevnih društvenih interakcija koje se odvijaju na njezinom prostoru. Korištenje prostora glavne ulice povezano je sa strategijama korištenja slobodnog vremena, potrebom za druženjem i komunikacijom. Navedena identitetska mjesta uglavnom su javni otvoreni prostori koji su pogodni za stvaranje društvenih aktivnosti i socijalnih interakcija, koje doprinose povećanju zadovoljstva životnim prostorom i osjećajem privrženosti za njega. Riječima Ivana Rogića (1992.: 122), javni prostor i identitetska mjesta resurs su lokalnog stanovništva za socijalizaciju, što daje osjećaj aktivne participacije i inkluzivnosti. Iako je riječ o javnim mjestima, ona su istovremeno „privatna“ jer su povezana s psihološkim značenjima i od simboličke važnosti za svakodnevni život neke zajednice koja to mjesto svakodnevno preoblikuje i stvara (Lipovec, 1997.: 6).

\section{Aspekti privlačnosti života unutar dubrovačke stare jezgre}

Kvaliteta života ovisi o brojnim čimbenicima. U najširem smislu riječi kvaliteta života obuhvaća osjećaj ugode mjesta i mogućnost ostvarivanja fizičkih i širih društvenih potreba (Seferagić, 1988.: 17). Kod pitanja o percipiranim prednostima života unutar dubrovačke stare jezgre sudionici su dominantno isticali dva aspekta: dostupnost (blizina društvenim i drugim potrebnim sadržajima i uslugama) te ambijentalnu posebnost stare gradske jezgre (urbani parter). 


\subsection{Dostupnost}

Dubrovačka stara jezgra, posebice tijekom turističke sezone, popunjena je domaćim i stranim posjetiteljima te popratnim kulturnim i društvenim sadržajima, što ostavlja dojam vitalnosti i živosti. Tako jedna sudionica navodi:

Posebnost života u Starom Gradu je, što se ono reče, iz pidžame si već na Stradunu. Ja čujem muziku, nešto se dogada, i u dva minuta sam na Stradunu. U ponoć, dvije ure kad me netko nazove uvijek si tu, ne moraš reći da se moraš obući, čekati autobus pa doci u Grad, ja sam u Gradu. (T. K.)

S njezinim navodima složio se i drugi sudionik:

Uvijek mi je bilo zanimljivo ovdje živjeti jer mi je sve blizu, posebno ljeti, sva dogadanja, klubovi i kaficí. Doslovno mi je ispred kuće, nisam morao nigdje autobusom. Druga stvar koja mi je jako bitna je blizina škole, fakulteta, nisam morao nigdje pješačiti duže od deset minuta. (T. P.)

Iako nije istaknuto samim navodima sudionika, primjetno je kako, osim dostupnosti, ugodnost stanovanja unutar stare jezgre proizlazi iz njezine pristupačnosti (pješačka zona) i relativne opremljenosti sadržajima, koje su ključne za svakodnevno funkcioniranje lokalnog stanovništva. Također, koncentriranost društvenih sadržaja u ljetnim mjesecima unutar stare jezgre povezano je i s mogućnošću društvene interakcije i komunikacije među stanovnicima, što je jedan od ključnih aspekata mjesta i proizvodnje simboličkog značenja i osjećaja pripadnosti (Čaldarović i Šarinić, 2015.: 152).

\subsection{Ambijentalna posebnost}

Osim spomenute dostupnosti i blizine sudionici su navodili ambijentalnu posebnost jezgre kao aspekt privlačnosti, što je istaknuto i u knjizi Periferijski puls u srcu od grada (Rogić, 1992.), gdje usprkos inferiornim uvjetima života stare jezgre imaju privlačnu snagu za život. Tako jedan sudionik navodi:

Nisam nikad promislio poći i napustiti ovo mjesto mog rodenja, tako me puno veže ispred kuce, imam predivnu taracu, što je rijetkost za Stari Grad - pogled na cijeli Grad, pogled na Malu Braću, crkve, more, zidine, Lovrijenac. (S. H.)

Svoju privrženost ambijentalnoj posebnosti jezgre istaknuo je i drugi sudionik:

Ona ima dosta malih skrovitih mjesta, i nakon trideset godina $i$ dalje me redovito oduševljava s detaljima i glavnim značajkama. Koliko god živim tu, uvijek otkrijem neke nove detalje, cijela je mistična i ambijentalna. Jako je neobično biti okružen ka- 
menom, covjek je nekako naviknuo na moderne detalje, asfalt, a ona te stavi doslovno petsto godina u prošlost. Đardini u gradu su skrivene oaze, neopisivo je koliko je ljepote uklopljeno u taj kamen. (I. R.)

Dosadašnja istraživanja pokazala su da ispitanici kao glavni izvor atraktivnosti i svoje privrženosti nekom mjestu navode ambijent "kakav se ne može naći nigdje drugdje“ (Rogić, 1992.: 124). Stara jezgra kao jedinstvena simbolička i estetska cjelina tako djeluje i kao odrednica identifikacije i privrženosti mjestu u kojem obitava lokalno stanovništvo. Svako mjesto rezultat je odnosa akcije (svakodnevnih praksi), koncepcija o njemu (zamišljenih i realnih) te fizičkih atributa. Kroz te sastavnice stvara se i specifičan osjećaj mjesta, koji podržava naš osjećaj identiteta koji je ukorijenjen u mjestu. Fizički atributi ili ambijentalne posebnosti mjesta djeluju kao više ili manje vidljive granice koje to mjestu definiraju i oblikuju. Pojavljivanje tog mjesta u pojedinom urbanom ili prirodnom okruženju može biti jedan od njegovih najvidljivijih atributa (Relph, 1976.: 30). No, uvijek je riječ o kombinaciji prirodnih (fizičkih) te simboličkih značenja koja su u ta mjesta upisana.

\section{Uzurpacija svakodnevice}

Uz aspekte privlačnosti života unutar stare jezgre lokalno stanovništvo suočava se $s$ procesima koji su uglavnom nastali kao posljedica razvoja turizma. Sudionici su posebno istaknuli tri takva trenda: sužavanje životnog prostora, sadržajna neopremljenost te iseljavanje lokalnog stanovništva.

\subsection{Sužavanje životnog prostora}

Sužavanje životnog prostora, koje su navodili sudionici, ukazuje na otežano obavljanje svakodnevnih aktivnosti, što dovodi u pitanje inkluzivni i vitalni potencijal stare jezgre. Javni prostor stare jezgre uglavnom se prilagođava ponudi i potražnji - potrošnji, turizmu i ugostiteljskim djelatnostima, što je vidljivo kroz porast broja restorana (stolova i stolica) koji smanjuju prohodnost javnog prostora. Tako je jedan sudionik naveo:

Ulica se najvise promijenila s dolaskom restorana, kroz devedesete je bilo doslovno sve naše $i$ onda u roku unazad dvije do tri godine su nikli ti restorani $i$ sad ljeti ne možeš ni prolaziti, a ne igrati nogomet. Ja izbjegavam ovu ulicu za prolaziti jer nema smisla, ne možeš proći, lokalno stanovništvo osjeća kao da je ugroženo i da im se oduzima životni prostor. (I. R.)

S njegovim navodima složile su se i druge sudionice navodeći okupiranost glavne ulice, ili najšire ulice u staroj jezgri, koja je danas „sve samo ne široka“: 
Nisam zadovoljna što se dopušta da se stavljaju stolovi gdje nikad nisu bili i to me strašno smeta. Stradun je za šetati. (P. D.)

Široka ulica postala je jedna od užih ulica zbog restorana i stolova, tako da se morati mimoilaziti s drugima, morate pustiti jednog da prode, a ulica je zapravo široka preko deset metara, općenito ta ulica je sad kompletno u restoranima i svoju svrhu je davnih dana izgubila. (T. K.)

Prema navodima sudionika, primjetno je kako se životni prostor lokalnog stanovništva podređuje komercijalnim i turističkim sadržajima, koji se pak orijentiraju isključivo na odnos ponude i potražnje zanemarujući simbolički aspekt javnog prostora koji proizlazi iz svakodnevnog života lokalnog stanovništva, a time i interese običnih ljudi koji u tom prostoru obitavaju. Drugim riječima, upotrebna vrijednost javnog prostora i interesi običnih ljudi sve se češće zamjenjuju komercijalnim vrijednostima prostora. U ovom slučaju transformaciju pješačke staze u zonu ugostiteljskih štekata vidimo i kao oduzimanje mogućnosti za društveno oblikovanje prostora (,igranje nogometa“) zbog dominantne logike proizvodnje prostora koji se orijentira na turizam i potrošnju, iz čega proizlazi osjećaj nemoći i nelagode kod lokalnog stanovništva.

\subsection{Sadržajna neopremljenost}

Osim sužavanja javnog prostora, sudionici su istaknuli sadržajnu neopremljenost kao sve veći problem u obavljanju svakodnevnih aktivnosti. Opremljenost označava postojanje sadržaja koji svakodnevni život čine ugodnijim i opuštenijim (Slavuj, 2012.: 72). Dostupnost označava raznovrsnost sadržaja, čime se smanjuje potreba za odlaskom izvan mjesta stanovanja u kontekstu zadovoljavanja osnovnih potreba (Slavuj, 2012.: 72). Upitani o zadovoljstvu sadržajnom opremljenošću stare jezgre sudionici su uglavnom navodili nedostatak trgovina svakodnevne uporabe:

Volio bih da ima više stvari za kupiti, poput Konzuma da ne moraš ići u Župu napraviti veliku spenzu. Druga stvar, problem ti je recimo daljina bolnice, problemi s prijevozom u bolnicu, hitna. (D. M.)

Sadržajna neopremljenost povećava nezadovoljstvo životom unutar stare jezgre, a time su posebno ugrožene osobe starije životne dobi. Transformacija stare gradske jezgre odvija se u skladu s tekovinama turizma i prilagođava stjecanju profita. Tako je došlo do prenamjene obrtničkih u uslužne djelatnosti, odnosno zatvaranja malih tradicijskih obrta:

Sadržaj je nula, kad sam bio mlad mogao sam poći kupiti iglicu za šivanje, uzeti bateriju, prije je bilo dvadeset butiga u Dubrovniku, bilo je za uzeti pjate, teće, mašinu za robu, špaher, peglu, sad nema ništa. (A. S.) 
Osim zatvaranja malih tradicijskih obrta, vidljiv je i porast paleotercijarnih (Rogić, 1992.: 47) djelatnosti:

Ondje gdje su bili čavli i alati su suvenirnice. Ondje gdje su bili iglice, konci su suvenirnice. Ne treba nam tisuću suvenirnica. Mislim, da su te suvenirnice nešto, nego prodaju kinesku robu. (A. R.)

Posljednji iskaz sudionice ukazuje na porast broja djelatnosti koje autor Rogić (1992.: 47) opisuje kao djelatnosti kod kojih dominira tipičnost, masovnost, mala mogućnost izbora, reducirana kvaliteta, nepovezanost s aspiracijama građana i koje svojim cijenama često nisu dostupne lokalnom stanovništvu te povećavaju osjećaj nezadovoljstva i isključenosti.

\section{3. Život u nestajanju: pad broja stanovnika $i$ iseljavanje iz jezgre}

Stara jezgra suočava se s trendom opadanja broja stanovnika uz negativan demografski saldo (Vidak i Sindik, 2013.: 113). Iako ne postoje točni podaci, procjenjuje se da se posljednjih desetak godina broj stanovnika nastavio smanjivati te da stara jezgra broji do 1500 stanovnika, uglavnom starije životne dobi (Klempić Bogadi, Vukić i Čaldarović, 2018.: 36) ${ }^{4}$. Takav trend vidljiv je po praznim ulicama i igralištima na kojima su se nekoć igrala djeca. Prema istraživanju autora Vidak i Sindik (2013.: 129), omjer mladog i starog stanovništva sve je veći, tako je i u školama zabilježen značajan pad upisanih učenika u prvi razred. Stara jezgra postaje neprivlačna za život posebice mladima, ali i djeci, kojoj se sužava prostor za igru. Svoje nezadovoljstvo iskazao je jedan od sudionika:

Jedan mi je svećenik rekao oko osamsto šezdeset, iako po meni je to realnije sigurno toliko jer sad oni govoru tisuću ipo ljudi, ne može biti tisuću ipo... Žalosno, nema male djece, e to je katastrofa za ovaj Grad. (S. H.)

Osim iseljavanja stalnog stanovništva, vidljiva je i prodaja nekretnina strancima, što prema autorima Vidak i Sindik (2013.: 113) ide u smjeru smanjenja funkcije stalnog stanovanja i pretvorbe stare jezgre u mjesto sekundarnog stanovanja. Ne postoji jedan i egzaktan uzrok iseljavanja lokalnog stanovništva. Radi se o spletu (ne)povoljnih čimbenika koji mogu potaknuti domaće stanovništvo na iseljavanje ili prodaju nekretnina. No, osim negativnih čimbenika, lokalno stanovništvo prodajom nekretnine

${ }^{4}$ Prema spomenutoj sociodemografskoj studiji Dubrovnika, najdominantnije djelatnosti unutar jezgre upravo su one povezane s turizmom: trgovina, ugostiteljstvo i promet. Godine 2011. više od polovine zaposlenih radilo je u tercijarnim djelatnostima (pružanje smještaja, priprema i posluživanje hrane, trgovina na veliko i malo) (Klempić Bogadi, Vukić i Čaldarović, 2018.: 41). Nakon tercijarnih slijede kvartarne djelatnosti (obrazovanje, kultura, znanost). Polovina sudionika ovog istraživanja također živi od turizma (neki primarno, neki sekundarno), dok su ostali zaposleni u kvartarnom sektoru. 
unutar stare jezgre može si osigurati pristojan život. Potaknuti visokim životnim troškovima i troškovima održavanja, a mogućnošću zarade, lokalno stanovništvo iseljava iz stare jezgre, a svoje nekretnine preuređuje u apartmane ili prodaje strancima. Da je tome tako, pokazuje izrazit nesrazmjer ukupne populacije tijekom ljeta i zime. U stambene prostore doseljava se bogatija elita, koja svoje nekretnine koristi najčešće u ljetnom periodu, dok su izvan sezone uglavnom prazni. Iseljavanjem preostalog stanovništva, stara jezgra ima potencijal postati mjesto sekundarnog stanovanja, odnosno postati pravo apartmansko naselje s promijenjenom socijalnom strukturom stanovništva. Tako jedan sudionik navodi:

Imaš mali dio ljudi koji živi ali većinom je to preuređeno u apartmane koji se izdavaju turistima, općenito cijeli Stari Grad je postao jedan veliki apartman. Tu živi zimi možda nekih petsto stanovnika, iako ih je prijavljeno devetsto jer ljudima je isplativije poći u podstanare a iznajmljivati svoju kuću ili stan u Starom Gradu jer gledaju da što manje rade, a što više zarade. (T. P.)

Osjećaj praznine posebno se osjeća u vremenu izvan turističke sezone kroz napuštene javne prostore, zatvorene ugostiteljske objekte, što ne priliči mediteranskom gradu, čiji se urbani identitet zasniva na životu unutar jezgre i javnim prostorima svakodnevnog života (Rogić, 1992.: 122). Međutim, ovdje treba ukazati na to da se ipak radi o kompleksnijem procesu. Naime, prema navodima sudionika većina stanovnika unutar stare jezgre svoje kuće i stanove prenamjenjuje u apartmane te odlazi živjeti u podstanarstvo izvan stare jezgre. To s jedne strane ukazuje ne samo na problematičnost turizma, u smislu povećanja troškova života i smanjivanja potrebnih sadržaja, već i na to da je i samo lokalno stanovništvo sudionik procesa i poticatelj percepcije „života u nestajanju“. Dakle, iako nisu jedini ni najvažniji akteri, ne smije se zanemariti uloga lokalnog stanovništva kao važnog subjekta spomenutih procesa. Uloga je lokalnog stanovništva višestruka; s jedne strane mogu se promatrati kao žrtve povijesti i kulture, no taj se dojam djelomično poništava svakodnevnim aktivnostima i praksama, koje navode na zaključak da je lokalno stanovništvo aktivni sustvaratelj i poticatelj fizičkih i socijalnih promjena unutar dubrovačke stare jezgre. Višestruka uloga lokalnog stanovništva posebno je izražena kod mlađih generacija, koje svoju priliku za boljim životom vide $\mathrm{u}$ prilici iseljavanja i iznajmljivanja apartmana. No, s druge strane još uvijek se unutar gradske jezgre osjećaju kao „kod kuće“, što je vidljivo kroz njihove iskaze o uporišnim mjestima unutar jezgre.

\section{Višestrukost identiteta lokalnog stanovništva}

Upitani o mogućnostima revitalizacije stare jezgre sudionici priželjkuju donošenje mjera u tri različite sfere: mjere za poticanje useljavanja, mjere za opremanje stare jezgre potrebnim sadržajima i mjere za regulaciju turizma. U kontekstu poticajnih mjera za poticanje useljavanja u staru jezgru sudionici su navodili sljedeće: 
Treba priuštiti stanovanje mladima i obiteljima pod prihvatlivim cijenama. (R. S.)

S tim navodom složio se i drugi sudionik:

Treba uvesti povlastice ljudima koji su spremni živjeti u gradu, ali i zadržati preostale tu ne samo zbog ljubavi prema kamenu nego jer imaju kvalitetan život. (I. R.)

U kontekstu potrebnih sadržaja, sudionici su uglavnom isticali važnost revitalizacije tržnice, otvaranja vrtića i renoviranja škole.

Treba vratiti placu, ljudi koji su ostali u Gradu ne žive direktno od turizma i treba im osigurati pristojne uvjete za življenje. (P. D.)

Trebalo bi napraviti vrtić, škole malo modernije kako bi se privukao odredeni broj ljudi ili da se vrate oni koji su otišli. (R. S.)

Povratak sadržaja poput trgovina i sadržaja za mlade sudionici smatraju ključnim mjerama za privlačenje novih stanovnika, zadržavanje postojećih, ali i mogući povratak starih stanovnika koji su svoje nekretnine odlučili pretvoriti u apartmane. Na kraju su se sudionici osvrnuli i na problematiku turizma:

Moramo stvoriti svoje ja, mi živimo od turizma, ali moraju se znati neka pravila ponašanja. (I. R.)

Osim potrebe za zaštitom običaja, kulture i autentičnosti svakodnevnog života unutar gradske jezgre, jedan je sudionik istaknu potrebu za ,skladom“:

Treba biti sklad, da možemo živjeti, probudit ćemo se jedno jutro i morat ćemo reći good morning. (S. H.)

Na kraju, čini se kako postoji svjesnost o ekonomskoj i financijskoj korisnosti turizma, no $s$ druge strane postoji snažan poriv da stara jezgra ipak ostane mjesto stanovanja običnog čovjeka. Sudionici stoga iskazuju važnost očuvanja autentičnih crta svakodnevnog života, imajući na umu važnost turizma za sveukupnu zajednicu.

$\mathrm{Na}$ temelju prethodnih podataka možemo uočiti da se interesi lokalnog stanovništva odvijaju u dva naizgled proturječna smjera: $s$ jedne strane lokalno stanovništvo iseljava iz gradske jezgre i prenamjenjuje kuće ili stanove u apartmane (nastoje živjeti od turiz$\mathrm{ma}$ ), dok s druge strane iskazuju interes i želju za revitalizacijom života gradske jezgre. Lokalno stanovništvo stoga podrazumijeva više identitetskih kategorija: od stanovnika svoje gradske ulice do domaćina turistima. U tom smislu identitet lokalnog stanovništva i privremenog (sezonskog) ili trajnog identiteta domaćina ne moraju se nužno poništavati. Identitet stanovnika baza je na koju se nadograđuju drugi ili sekundarni 
identiteti, a koji mogu biti komplementarni. Samim time što preuzimaju identitet domaćina turistima, mogu s jedne strane biti promotori turizma (u pozitivnom smislu) od kojeg jezgra živi, ali i osjećati snažniju vezu s prostorom u kojem stanuju i rade. Biti domaćin turistima ne znači da jezgra ne ostaje poželjnim mjestom za život. Možda upravo zbog toga što su domaćini turistima, nastoje djelovati kao čuvari identiteta i posebnosti jezgre, svjesni ekonomske funkcije turizma za jezgru kao prepoznate turističke destinacije.

\section{Zaključak}

Cilj ovog rada bio je istražiti iskustvo života unutar dubrovačke stare jezgre iz perspektive lokalnog stanovništva.

Dubrovačka stara jezgra oduvijek je smatrana poprištem društvenog života. Zbog svoje jedinstvenosti, iznimne estetske i ambijentalne kvalitete stara jezgra čini identitet grada u cjelini. No, identitet se ne oblikuje samo u kontekstu grada kao fizičke strukture ili turističkog proizvoda, već kao dio identiteta stanovnika koji žive unutar gradskih zidina. Tako unutar dubrovačke stare jezgre postoje uporišna mjesta / značajni lokaliteti koji su istovremeno identifikacijska mjesta lokalnog stanovništva. Oni imaju simboličko značenje i značajnu ulogu kao mjesta u kojima se odvijaju formalne i neformalne svakodnevne i povremene društvene prakse. Iz istog razloga kažemo da su ta mjesta identitetska, ali i funkcionalna za svakodnevni život njegovih stanovnika. Sudionici su često isticali kako žele živjeti unutar dubrovačke stare jezgre te, s obzirom na dosadašnje iskustvo i vezanost za taj prostor, ne priželjkuju njezinu promjenu. Blizina društvenim i kulturnim sadržajima te niz ambijentalnih posebnosti istaknuti su kao faktor privlačnosti za život unutar jezgre.

Uz spomenuto simboličko značenje, odgovori sudionika ukazuju na to da su i sami svjedoci promjena koje se događaju unutar jezgre, ponajprije potaknutih turizmom, te koje neupitno mijenjaju svakodnevno življeno iskustvo i simbolički doživljaj prostora. Ambijentalnost koja je navedena kao faktor privlačnosti često se koristi kao resurs za turizam, odnosno kao proizvod za potrošnju. Tako je stanovništvo istaknulo nekoliko trendova: povećanje broja ugostiteljskih objekata i njihovo širenje na javnim površinama, sadržajnu (ne)opremljenost ili funkcionalnu neselektivnost koja proizlazi iz snažne turistifikacije dubrovačke stare jezgre. Čini se kako je lokalno stanovništvo i samo postalo žrtva vlastite povijesti i kulture. Kao dodatan problem ističe se kako staru jezgru sve više napušta lokalno, ponajprije mlado stanovništvo, a nekretnine se prenamjenjuju u apartmane ili se prodaju, što ostavlja dojam kako je život stare jezgre u nestajanju.

$\mathrm{Na}$ temelju prethodnih podataka možemo uočiti da se interesi lokalnog stanovništva odvijaju u dva naizgled proturječna smjera: s jedne strane lokalno stanovništvo iseljava 
iz gradske jezgre i prenamjenjuje kuće ili stanove $\mathrm{u}$ apartmane, dok $s$ druge strane iskazuju interes i želju za revitalizacijom života gradske jezgre. Lokalno stanovništvo stoga podrazumijeva više identitetskih kategorija: od stanovnika svoje gradske ulice do domaćina turistima. Ponajprije treba imati na umu da lokalno stanovništvo nije jedini poticatelj promjena unutar dubrovačke stare jezgre. Ona je pod snažnim političkim i ekonomskim utjecajima. No, ne smije se zanemariti uloga lokalnog stanovništva kao važnog subjekta spomenutih procesa.

U ovom slučaju lokalna svijest odraz je svakodnevnog iskustva koje treba biti polazište, upozorenje i pomoć u identifikaciji poželjnih transformativnih mogućnosti same jezgre - kao turističke destinacije i poželjnog mjesta za život.

\section{Literatura}

1. Bauman, Z. (2011). Tekuća modernost. Zagreb: Naklada Pelago.

2. Castells, M. (2000). Uspon umreženog društva. Zagreb: Golden Marketing.

3. Creswell, J. (2007). Qualitative inquiry and research design. Choosing among five approaches. Thousand Oaks: SAGE Publications.

4. Čaldarović, O. i Šarinić, J. (2015). Suvremena sociologija grada. Od nove urbane sociologije prema sociologiji urbanog. Zagreb: Naklada Jesenski i Turk.

5. Čaldarović, O. i Šarinić, J. (2017). Suvremeni grad. Javni prostori i kultura življenja-primjer Zagreba. Zagreb: Naklada Jesenski i Turk.

6. De Certeau, M. (1984). The Practice of Everyday Life. Los Angeles: University of California Press.

7. Gulin Zrnić, V. (2009). Kvartovska spika. Značenje grada i urbani lokalizmi u Novom Zagrebu. Zagreb: Institut za etnologiju i folkloristiku, Naklada Jesenski i Turk.

8. Jelinčić, D. (2006). Turizam vs. Identitet. Globalizacija i tradicija. Etnološka istraživanja, 11: 161-183.

9. Kalčić, S. (2013). Flanerizam kao performativna metoda i motiv u suvremenoj umjetnosti. Časopis za suvremena likovna zbivanja, 4 (7): 77-93.

10. Klempić Bogadi, S.; Vukić, J. i Čaldarović, O. (2018). Sociološko-demografska studija. Život u povijesnoj jezgri Dubrovnika. Dubrovnik: Zavod za obnovu Dubrovnika.

11. Krasny, E. (2015). Pravo na grad i pravo na zeleno. Zarez: dvotjesnik za društvena i kulturna zbivanja, ožujak 2015.

12. Leboš, S. (2009). Po-imanje grada: Pledoaje za transdiciplinarno proučavanje urbaniteta Zagreba. Etnološka tribina, 32 (39): 75-90.

13. Lipovec, N. (1997). Prostor i mjesto. Prostor, 1 (13): 1-34.

14. Low, S. (2006). Promišljanje grada. Studija iz nove urbane antropologije. Zagreb: Naklada Jesenski i Turk. 
15. Lukermann, E. F. (1964). Geography as a Formal Intellectual Discipline and the Way in Which it Contributes to Human Knowledge. Canadien Geographer, 8 (4): 167-172.

16. Relph, E. (1976). Place and Placelessness. London: SAGE Publishing Ltd.

17. Rogić, I. (1992). Periferijski puls u srcu od grada: zamke revitalizacije. Zagreb: Sociološko društvo Hrvatske.

18. Seferagić, D. (1988). Kvaliteta života i nova stambena naselja. Revija za sociologiju, 19 (1-2): 117-119.

19. Slavuj, L. (2012). Kvaliteta života u odabranim susjedstvima Grada Rijeke. Hrvatski geografski glasnik, 74 (2): 69-88.

20. Stiperski, Z. (2015). Percepcija mjesta ugode i neugode u prostoru grada Zagreba. Anketno istraživanje. Prostor, 2 (50): 332-343.

21. Tuan, Y. (1977). Space and Place: The Perspective of Experience. Minneapolis: University of Minessota Press.

22. Vidak, N. i Sindik, J. (2013). Analiza sadržaja novinskih napisa o kupoprodaji nekretnina u staroj gradskoj jezgri Dubrovnika (1995-2006). Anali Dubrovnik, 52 (2): 609-649.

23. Vukić, J. (2019). Gradski projekt. Prostor središta Trešnjevke. Sociološka studija. Zagreb: Grad Zagreb. 


\title{
To Live Inside Dubrovnik's Historic Core - The Perspective of the Local Community
}

\author{
Nika $\oplus$ uho \\ Catholic University of Croatia, Department of Sociology, Zagreb, Croatia \\ e-mail:nika.djuho@unicath.hr \\ Maja Golubić \\ Catholic University of Croatia, Department of Sociology, Zagreb, Croatia \\ e-mail:mgolubic@unicath.hr \\ Karlo Tukša \\ Catholic University of Croatia, Department of Sociology, Zagreb, Croatia \\ e-mail:ktuksa@unicath.hr
}

\begin{abstract}
The aim of this paper was to explore the symbolic meanings and experience of life within Dubrovnik's historic core. Dubrovnik's historic core has a difference in meaning compared to other cities' parts, and is today recognized as a popular tourist destination. The experience of living within Dubrovnik's old core was examined on the example of the local community - the study included 9 participants who were born and are still living inside the historic core. As part of this research, only qualitative methodology was used, in two phases. In the first phase of the research, the technique of narrative urbanism was used - collecting data through a conversation and walking around specific localities within the core, through which we were guided by the participants themselves. In the second phase of the study, the technique of semi-structured interview on the same sample of the local community was applied. The main findings suggest that the main attraction of life is the availability of different contents and the ambiental distinctiveness of the historic core. Nevertheless, it appears that the local community is becoming a victim of their own history and culture, through examples of the usurpation of everyday life and the perception of life in disappearance. The specific orientation of this research as well as the statements of the participants can serve as a warning and starting point in identifying the desirable transformational possibilities of Dubrovnik's historic core with its dual role - as a tourist destination and a desirable place of living. However, a more detailed analysis suggests that the identity of the local community is not static, and that is realized through two complementary categories: the category of local community and host community.
\end{abstract}

Key words: Dubrovnik's historic core, local community, narrative urbanism, city story. 